\title{
Conceptual Framework of the Green Economy for Oil Palm
}

\author{
Wisakha Phoochinda ${ }^{1}$ \\ ${ }^{1}$ Graduate School of Environmental Development Administration, National Institute of Development \\ Administration, Thailand \\ Correspondence: Wisakha Phoochinda, Graduate School of Environmental Development Administration, \\ National Institute of Development Administration, Thailand. E-mail: wisakha.p@nida.ac.th
}

Received: November 3, 2017

Accepted: February 10, 2018

Online Published: March 30, 2018

doi:10.5539/jsd.v11n2p25

URL: https://doi.org/10.5539/jsd.v11n2p25

\begin{abstract}
The study aimed to investigate operation of oil palm industry based on Green Economy concept. The conceptual framework of the Green Economy for the oil palm industry was established in accordance with Thailand's context. Information was compiled via literature review on definition, meaning, concept, and theory of the Green Economy, and the oil palm industry, as well as interviews with 15 specialists, experts, scholars, farmers, and officials of relevant agencies such as the Ministry of Agriculture and Cooperatives.The information from the interviews was analyzed by grouping issues and content analysis, and description to obtain the conceptual framework. Then, the framework was assessed by specialists, experts, and officials from the Ministry of Agriculture and Cooperatives with expertise in oil palm, and farmers for implementation.

The study findings revealed that the application of the conceptual framework of the Green Economy for the oil palm industry consisted of the Sufficiency Economy Philosophy, Roundtable on Sustainable Palm Oil (RSPO), economic development such as development of organic farming, management of yields and waste, social development such as better quality of life for farmers, higher negotiating power for farmers, equality; and environmental development such as balanced eco system, reduced impact on the environment, and use of environmental-friendly technology.
\end{abstract}

Keywords: oil palm, green economy, conceptual framework

\section{Introduction}

For many years, nations around the world have experienced food shortage crisis, creating worries for the global food situation. In the future, the increasing world population will impact the higher use of energy, food consumption, and water consumption. Moreover, the climate change has also affected the agricultural development worldwide. Consequently, the global arena has joined hands in driving the "Green Economy" to be used as a tool in sustainable development, returning balance back to the society and the environment. Presently, the agricultural process of Thailand's economic crops lacks systematic development management and clear and concrete direction. It constitutes one reason why Thailand faces the problems of the plunging economic crop prices, the lack of farming efficiency, and farmers' hardship. Coupled with the lack of good and efficient irrigation system in Thailand, problems have emerged in farming. Thailand's agricultural sector still faces numerous problems including limited farmland, irrigation problems, and shortage of water sources. As a result, there is reduced production efficiency and loss in the entire food production chain. There is also the problem of labor shortage in the agricultural sector, farmers' insufficient income, fluctuating agricultural prices, lack of continuous industry to support agricultural yields, as well as the lack of clear implementation according to the government's policy, unbalanced transport system, high production costs, lack of balance and appropriateness of the land use for agriculture. Moreover, Thailand faced the energy crisis in 2016 with import of energy valued over 680,868million baht, the highest import being crude oil (Ministry of Energy, 2017). If Thailand has to totally rely on the import of energy, it will greatly impact the national energy security. These problems foresee food and energy crises in the near future. Therefore, Thailand needs to accelerate the strategies on the creation of security between food and energy crops.

Up till now, Thailand has applied the Green Economy concept to the food crop and energy crop industries, especially the oil palm industry, considered an important economic crop to the country's development in terms of alternative energy source. The relevant agencies have concretely supported the oil palm cultivation since 2004 by 
defining the Oil Palm Industry Strategies 2004-2009 in order to develop Thailand towards becoming the center of oil palm and oil palm-based chemical industries in the Indochinese Peninsula and promote the increased use of biodiesel from palm oil by promoting the potential of the production of Thailand's biodiesel from the capacity of merely 62.1 million liters a day to 97.5 million liters a day by 2021 according to the Alternative Energy Development Plan for 25 percent in 10 years (2012-2021) and the 20 year Oil Palm and Palm Oil Restructuring Strategies (2016-2036).The Oil Palm Subcommittee aims to develop Thailand's oil palm and palm oil industries towards the oleochemical industry such as vitamin E and diesel for aircraft, upgrade farmers' income to expand land for palm cultivation, focus on the restructuring of oil palm in six aspects namely production, innovation, standard, energy, marketing, and management. The AEDP 2015 (2012 -2036) set the target to promote the production of 14 million liters of biodiesel a day by 2036 (Thailand Ministry of Energy, 2015). It results in the expansion of the oil palm industry in the future. But if the promotion of the oil palm cultivation is in excess and with no limit, the impact will be on the economic security. It derives from the palm prices due to overproduction or oversupply causing social impact on a wide scale such as conflict between locals such as farmers who grow oil palm as alternative energy and those who grow palm for food or conflict on land infringement for oil palm cultivation. There is also environmental impact such as toxic chemical residues from oil palm cultivation, pollution, and waste from the oil palm industry. Therefore, the application of the Green Economy concept in the oil palm industry is a way to drive the industry towards economic growth in parallel with environmental-friendly operation and eco system.

The researcher conducted a study to establish the conceptual framework of the Green Economy appropriate to Thailand's context by using the oil palm industry as a case study in order to develop the strategic plan of Thailand's Green Economy for the oil palm industry, leading to the promotion of the Green Economy concept to other relevant sectors. The objectives of this study included: Study the operation of the oil palm industry and Conduct analysis and establish the Green Economy concept of the oil palm industry in line with the Green Economy concept within Thailand's context

\section{Methodology}

In the study, the researcher conducted literature review from related documents and research reports, academic articles in Thailand and abroad on Green Economy in order to formulate the initial research framework. After document synthesis from document review, the conceptual framework of the Green Economy appropriate to Thailand's context derived from the research entitled the Green Economy concept within Thailand's context with the case study of oil palm and palm oil industries is applied to the oil palm industry. The analysis was conducted to establish the conceptual framework of the Green Economy for the oil palm industry in line with the Green Economy concept within Thailand's context, by compiling information on the oil palm industry to develop the conceptual framework of the Green Economy in the oil palm industry. Invitation was sent out for experts from various agencies related to the entire system of Thailand's oil palm industry for brainstorming session to establish the Green Economy concept of the oil palm industry. Then, the conceptual framework and the composition of the Green Economy of the oil palm industry were put to test. Opinion survey was conducted for relevant persons, from oil palm growers, raw palm oil processing plants, and pure palm oil processing plants, as well as experts and specialists from the Ministry of Agriculture and Cooperatives. The test result would lead to the development and improvement of the conceptual framework and the composition of the Green Economy in the oil palm industry in line with real situations and with concrete implementation for public dissemination and formulation of the strategy to drive Thailand's Green Economy in the future. The topics of literature review include: Green Economy or Green Growth, Sufficiency Economy Philosophy, Sufficiency Economy and Green Economy, Conceptual framework of Thailand's Green Economy and Oil palm industry

The key informants of the study were as follows:

1) Lecturers, Faculty of Economics, Kasetsart University

2) Lecturers, School of Development Economics, National Institute of Development Administration

3) Top executives, Office of the National Economic and Social Development Board

4) Experts on oil palm, Agricultural Research Development Agency (Public Organization)

5) Experts, Office of Agricultural Economics

6) Officials from the Ministry of Agriculture and Cooperatives

7) Farmers group, Pong Nam Ron District, Chantaburi Province

8) Officials from the District Agricultural Extension Offices 
9) Oil palm growers in Pathum Thani, Chonburi, Chumphon, Krabi, and Trang Provinces

For the study, the researchers aligned the conceptual framework of Thailand's Green Economy with the Roundtable on Sustainable Palm Oil (RSPO) and Sufficiency economy philosophy and prepared the conceptual framework of the Green Economy in the oil palm industry as illustrated in Figure .1

\section{Conceptual Framework of Thailand's Green Economy}

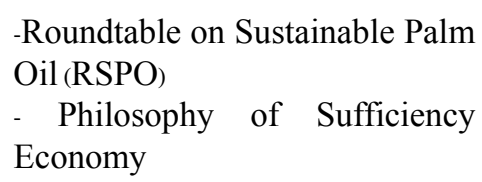

Conceptual Framework of the Green

Economy in the Oil Palm Indusry

Figure 1. Conceptual framework of the green economy in the oil palm industry

For the qualitative analysis of information of the study, the researchers used the interviews and brainstorming session with experts from relevant agencies for policy formulation. The representatives from the agencies relating to oil palm research conducted synthesis in conjunction with the survey result on the conceptual framework and the composition of the Green Economy, by conducting survey from the production supply chain of oil palm including those related to the oil palm industry in Thailand. Descriptive summary, content analysis, and relevant issues were grouped in order to learn of problems and obstacles. Feasibility analysis was then conducted to apply the conceptual framework of the Green Economy in the oil palm industry. The concept and the composition were then improved for accuracy, compliance with real situations, and concrete implementation. Finally, the test and brainstorming results were used to prepare the complete conceptual framework and composition of the Green Economy of the oil palm industry for public dissemination and formulation of the strategies to drive Thailand's Green Economy in the future.

\section{Study Findings}

\subsection{Definition, Concept, Theories, and Direction Development of Oil Palm Industry}

\section{Sustainable Development of the Oil Palm Industry}

The sustainable development of the oil palm industry was under the Green Economy principles. The Development Plan of the Oil Palm and Palm Oil Industries 2013-2017 supported the development. Its mission consisted in increasing the efficiency of oil palm production, oil palm and palm oil industries, as well as marketing based on good and environmental-friendly management. The objectives were as follows: 1) Increase potentials in production, marketing, knowledge base, and participatory management 2) Increase the potential of the oil palm and palm oil industries in the entire supply chain 3) Foster the cooperation between those involved in the oil palm industry between farmers and the industry and 4) Set up the management system, self-reliant management and competition in the long run with the objectives to promote and develop the sustainable and environmental-friendly oil palm and palm oil production.

The reduced emission of the greenhouse gas of the oil palm industry was conducted under the Green Economy concept as follows:

In response to the situation and operation both inside the country and abroad to promote the reduction of the greenhouse gas emission in the oil palm agricultural sector, and the promotion of the oil palm cultivation to reduce the greenhouse gas emission at the international level, the Roundtable on Sustainable Palm Oil (RSPO) was set up with the main objective of producing sustainable oil palm in countries around the world. Criteria, methods, and implementation guideline were determined so that farmers and palm oil processing plants could comply with. As each country had its own social and economic context and different palm oil production processes, the RSPO provided the opportunity for each country to determine its own criteria and indicators under the RSPO standard. The RSPO international standard determined the 8 Principles (RSPO, n.d) namely

1) Commitment to transparency and accountability 2) Compliance with law and regulations 3) Economic and financial compliance 4) Best practice for oil palm growers and palm oil processing plants 5) Responsibility towards the environment and preservation of natural resources and biodiversity 6) Responsibility towards personnel and communities affected by oil palm growers and palm oil processing plants 7) Responsibility towards oil palm cultivation in new areas and 8) Continuous development in major activities. Malaysia is very successful in certifying the RSPO standard for palm plantations with small farmers in the project under the management of Felda Group. Indonesia is the second exporter of palm oil in the world, after Malaysia. Thailand 
is in the process of driving the RSPO standard for recognition, with ready implementation by growers, palm oil processing plants, and palm oil refinery plants. Currently, some growers such as oil palm growers in Krabi Province already had the standard certification.

The direction to promote oil palm cultivation to reduce the greenhouse gas by agencies related to oil palm cultivation would focus on Good Agricultural Practice (GAP) such as soil nutrient analysis and leaf nutrient analysis, promotion of the use of organic fertilizer, landfill, as well as providing knowledge and understanding, counselling in plantation management, development of oil palm species for higher yield, together with the drive to establish the Oil Palm Act. At the same time, agencies related to oil palm industry would focus on the reduction of greenhouse gas emission by using the Zero Waste concept, meaning the reuse of waste from production process in the production process of the palm industry. Moreover, there was also promotion of environmental management such as installation of waste treatment system to reduce impact on the environment. Some companies also participated voluntarily in the project to reduce greenhouse gas emission such as request for carbon footprint label or participated in the Carbon Credit project. The agencies supporting the reduction of greenhouse gas emission in the oil palm industry would focus on the use of organic fertilizer in place of chemical fertilizer in oil palm cultivation, as well as innovation of palm oil press machine at the communal level to reduce production costs and reduce waste from the palm oil processing.

According to the relevant agencies, the main problems and obstacles to promote the oil palm industry in order to reduce the greenhouse gas emission were as follows: lack of funding, equipment, and personnel related to the promotion of the reduction of greenhouse gas emission. For instance, farmer were encouraged to use fertilizer in the palm plantations via leaf nutrient analysis. However, the labs for leaf nutrient analysis were limited and farmers were not capable to do their own analysis and needed experts, causing complications in the operation. Next was the lack of correct knowledge and understanding of the reduction of the greenhouse gas emission of the oil palm industry and the lack of concrete grouping of the oil palm industry which hindered the success of the reduction of the greenhouse gas emission. The recommendations of the agencies related to the promotion of the oil palm industry to reduce the greenhouse gas emission were as follows. The oil palm industry should be grouped, from growers to plants, to make joint efforts in reducing the greenhouse gas emission from the palm industry. Best Practice should be promoted to reduce the greenhouse gas emission in the palm industry for wider recognition. Knowledge should also be transferred to agencies related to the reduction of greenhouse gas emission of the oil palm industry.

The direction to support the oil palm growers to reduce the greenhouse gas emission derived from oil palm cultivation could be summarized as follows:

1) Set up Mechanism of Cooperation for the Reduction of Greenhouse Gas Emission and Oil Palm Production Costs.

It was found that the most suitable direction was to support the setting up of "Oil Palm Plantation Model "as a learning center for other farmers. The setting up of a palm plantation model would be a learning source for farmers as an example to reduce the greenhouse gas emission from the oil palm cultivation. With the established oil palm plantation model, there should be continuous monitoring and assessment of the operation of the oil palm plantation. The absence of monitoring and assessment would risk failure. Next was the support of soil analysis and leaf analysis for correct use of chemical fertilizer in oil palm care. The direction would allow farmers to know the amount of fertilizer to be used and helped them reduce the use of chemical fertilizer. Moreover, farmers would also be able to efficiently solve problems derived from the abnormalities of palm trees such as leaf curl disease, or leaf blight disease. The oil palm growers greatly needed the support as soil and leaf analysis had never been conducted.

2) Stimulate Joint efforts to Reduce the Greenhouse Gas Emission from Oil Palm Plantations.

It was found that the most suitable direction was to simulate the farmers to participate in the standard certification of oil palm cultivation such as GAP standard for oil palm cultivation through additional incentives such as better prices for the yields as there were measures to stimulate the farmers to become aware of the importance of the reduction of the greenhouse gas emission from oil palm cultivation. Next was the regulations to preserve the communal forest in order to prevent encroachment of forest or reserved forest. The measures would promote forestation and preserve natural resources for the community. But the promotion of such measures needed knowledge and understanding of relevant regulations as farmers did not have knowledge or understanding of communal forest preservation. The least suitable direction was to promote the standard certification of the emission of greenhouse gas from oil palm growers as oil palm growers still believed that oil palm cultivation was not responsible for greenhouse gas emission. They also lacked sufficient knowledge and 
understanding of the greenhouse gas from oil palm cultivation.

3) Research and Development of Technology to Reduce the Greenhouse Gas Emission from Oil Palm Growers.

It was found that the most suitable direction would be to promote the development of palm species with higher yield and reduce the use of chemical fertilizer. The measures needed knowledge from relevant agencies. For instance, for the development of palm species for efficiency and suitability of growth in each environment, oil palm growers must be really ready to participate in the promotion of the cultivation of the oil palm species. It was followed by the support to develop fertilizer or nutrient from oil palm waste such as foliar fertilization of oil palm or fertilization of oil palm empty fruit bunch. The oil palm growers viewed that the operation was quite difficult as the oil palm empty fruit bunch belonged to the palm oil processing plants and the palm oil processing plants might sell the oil palm empty fruit bunch to growers at higher prices. But if the palm oil processing plants cooperated in selling or giving the oil palm empty fruit bunch to the growers free of charge, the measures will reduce costs for oil palm growers, especially the costs of chemical fertilizers for cultivation. The least suitable guideline was the promotion of the use of technology for oil palm cultivation planning. For example, for the use of GIS to select suitable location for oil palm cultivation, the oil palm growers viewed that land management duplicated the growers' land rights. Moreover, budget of high investment was needed.

\subsection{Conceptual Framework of the Green Economy for the Oil Palm Industry}

The researcher applied the framework to develop Thailand's Green Economy to the development of the conceptual framework of the Green Economy of the oil palm industry by using the Roundtable on Sustainable Palm Oil (RSPO) and reducing the greenhouse gas emission of the oil palm cultivation. The researcher then summarized the guideline to promote the Green Economy of the oil palm agricultural sector for farmers, and assessed the suitability and feasibility of the implementation with experts from decision-level agencies responsible for the promotion of the direction to develop Thailand's Green Economy and those who worked in the field such as officials from District Agricultural Extension Offices, Subdistrict Agricultural Extension Offices, and farmers as illustrated in Figure 2. 


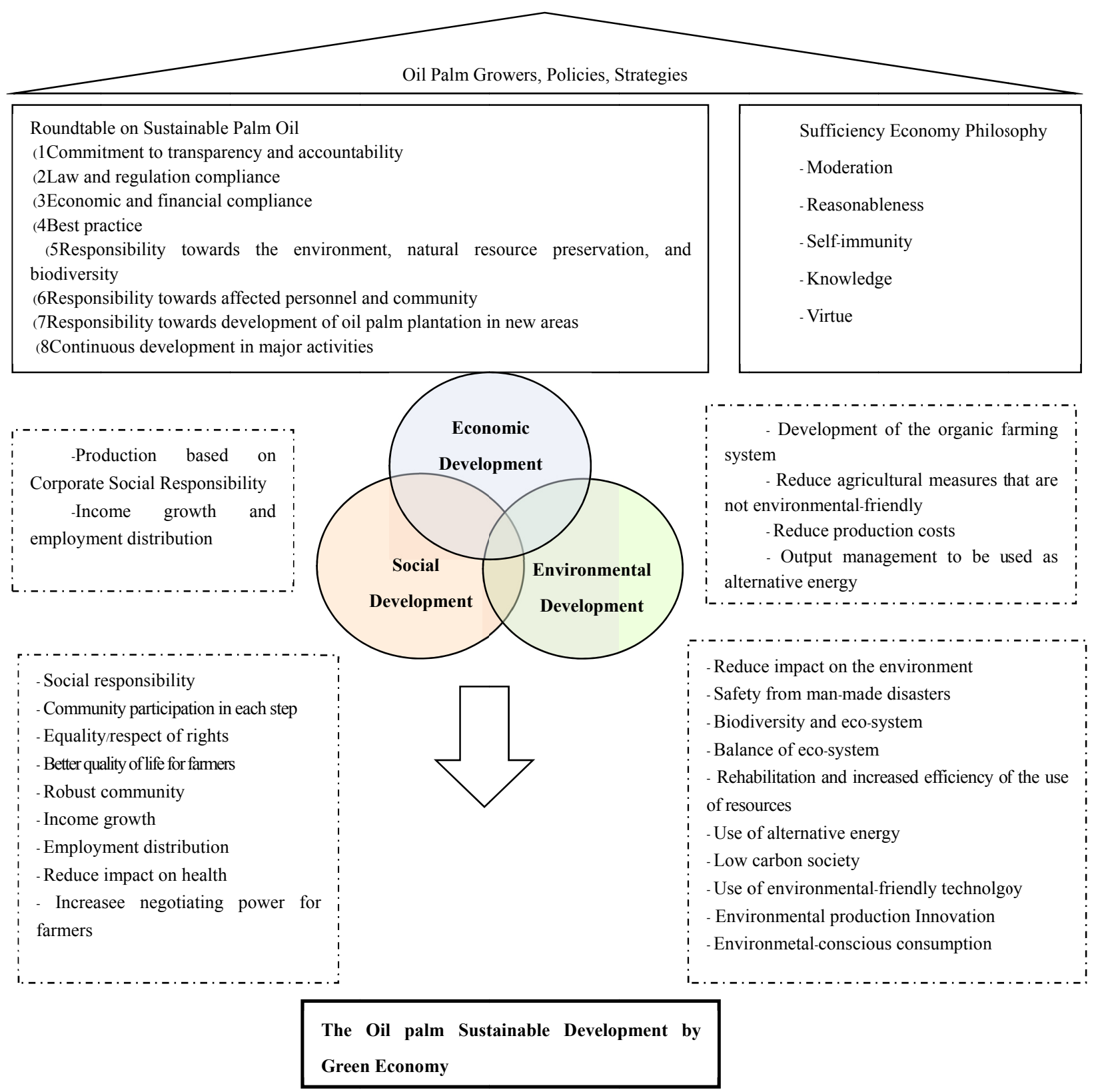

Figure 2. Chart of the conceptual framework of the green economy for the oil palm industry

\section{Conclusion, Discussions on the Study Findings, and Recommendations}

\subsection{Conceptual Framework of the Green Economy of the Oil Palm Industry in line with the Green Economy Concept within Thailand's Context}

The conceptual framework of the Green Economy of the oil palm industry by using the Roundtable on Sustainable Palm Oil (RSPO) as a guideline to promote the Green Economy for the oil palm cultivation consisted of the following: 1) Commitment to transparency and accountability such as disclosure of documents on the management to the public and adherence to morality in everty step of business operation and transaction 2) Law and regulations abidance such as compliance with law and relevant rules and regulation 3) Economic and financial compliance namely targeted management plan to foster long-term economic and financial security 4) Best practice meaning suitable practice and regular monitoring of performance 5) Responsibility towards the environment and preservation of natural resources and biodiversity 6) Responsibility towards affected personnel and community 7) Responsibility towards the development of oil palm cultivation in new areas, with planning, management, and operation, use of information of land survey and geography in the planning of the new oil 
palm cultivation and use the results for planning and operation in the areas 8) Continuous development in major activities, with regular monitoring and review of activities, formulating and implementing the action plan to illustrate the regular improvement of main operation in parallel with the Sufficiency Economy Philosophy as economic management suitable to Thailand (Committee on agriculture of RSPO, 2014). The development of the Green Economy in the oil palm industry should be under three aspects namely:

1) Economic aspect: Organic farming meaning nature-based agriculture, without toxic residue and avoidance of contamination from chemicals in the soil, water, and in the air to promote soil fertility, biodiversity, implementation of measures or regulations in the agricultural management, residual management, in order to reduce waste and use as biomass fuel.

2) Social aspect: Focus on quality of life of farmers according to the Sufficiency Economy Philosophy, with sufficient income for necessary and disposable expenses, moderation, time for relaxation, negotiating power to determine the oil palm selling prices for farmers' immunity, responsibility towards the society and the environment, equality in basic necessities, access to accurate information or knowledge, consideration of compensation for any damage, and ethic-based complaint for fairness.

3) Environmental aspect: There must be no impact on the environment, balanced eco-system, efficient use of resources, use of alternative energy such as solar energy, biomass energy, and wind energy to replace conventional energy, use of environmental-friendly technology, consumption of goods or products having no impact on the environment, study on the treatment and rehabilitation to systematically solve problems derived from production, target to develop and monitor the quality of environmental-friendly products, leading to environmental production innovation, reduction of man-made disasters, biodiversity in the eco system.

The researcher applied the conceptual framework to develop Thailand's Green Economy to develop the conceptual framework of the Green Economy of the oil palm industry, by using the Roundtable on Sustainable Palm Oil (RSPO) to set up the guideline to promote the Green Economy of the oil palm cultivation to the farmers. The guideline was then assessed for suitability and feasibility of implementation by experts from policy-making agencies relevant to the promotion of the guideline to develop Thailand's Green Economy. Practitioners on the site consisted of officials from the District Agricultural Extension Office and the Subdistrict Agricultural Extension Office, as well as farmers. In summary, the the Roundtable on Sustainable Palm Oil (RSPO) was summarized as a conceptual framework of the Green Economy of the oil palm industry which was suitable to oil palm growers and Thailand's oil palm industry. However, the unsuitable points included abidance by law and regulations, absence of legal support, and dependence of the standard of the oil palm production on the voluntarily act of the farmers. The conceptual framework of the Green Economy of the oil palm industry under the aspect of the economic development was suitable to oil palm growers and Thailand's oil palm industry. The unsuitable point was the development of the organic farming as the oil palm responded quite heavily to chemical fertilizer. The conceptual framework of the Green Economy of the oil palm industy under the aspects of social and environmental development was suitable to oil palm growers and the oil palm industry.

\subsection{Guideline to Promote the Green Economy in the Agriculture for Oil Palm Growers}

The guideline to promote the Green Economy in the agriculture for oil palm growers can be summarized as follows:

1) Focus on Good Agricultural Practice (GAP) to oil palm growers via the soil nutrient analysis and the leaf nutrient analysis to know the amount of nutrient needed by the palm trees, resulting in the sufficient amount of fertilizer for the needs of the palm trees, reduction of the unnecessary use of fertilizer, promotion of the use of organic fertilizer in place of conventional chemical fertilizer, creating toxic residues, and direct and indirect impact on the environment, landfill, providing knowledge, understanding, and counselling for plantation management, development of oil palm species with higher yield, and driving the establishment of the Oil Palm Act. At the same time, the agencies related to the oil palm industry would focus on the reduction of the greenhouse gas emission, by using the Zero Waste concept which was to reuse the waste from the production process in the production process of the palm industry. Moreover, the environmental management was promoted such as installation of waste treatment system to reduce environmental impact. Some companies also participated in the project for voluntary reduction of greenhouse gas such as request for carbon footprint label, as well as participation in the Carbon Credit project. The agencies supporting the reduction of greenhouse gas in the oil palm industry would focus on the promotion of the use of organic fertilizer in place of chemical fertilizer in the oil palm cultivation. It also included the invention of the communal palm oil press machine, reducing production costs, and reducing waste from the process of palm oil extraction.

2) Encourage oil palm growers to reduce the greenhouse gas emission from the process of oil palm cultivation as 
follows:

2.1 Foster cooperation mechanism to reduce greenhouse gas emission and reduce oil palm production costs. The most suitable guideline was to support the establishment of "oil palm plantation model "as a site of knowledge for other farmers to continuously follow-up and assess the operation of the oil palm plantation model.

2.2 Foster motivation of jointly reducing the greenhouse gas emission from oil palm cultivation, by supporting the farmers to participate in standard certification of oil palm cultivation such as GAP with additional incentives such as better prices on the yield, regulation to preserve communal forest to prevent encroachment of forest or preserved forest, as well as preserving community's natural resources.

2.3 Research and development of the technology to reduce the greenhouse gas emission of oil palm growers by promoting oil palm species with higher yields but reducing chemical fertilizer. The measure needed knowledge from relevant agencies such as for the development of palm species for efficiency and suitability to the growth in each environment, oil palm growers must be really ready to participate in the promotion to plant the palm species. The development of the fertilizer or the nutrient from oil palm waste such as foliar fertilization of oil palm, fertilization of oil palm empty fruit bunch, or the use of technology for oil palm cultivation planning such as the use of GIS to select suitable location for oil palm cultivation should be promoted.

\section{Recommendations}

1) The major problem to promote the Green Economy to the oil palm growers was that most growers lacked knowledge and understanding of the importance of the Green Economy, as well as the reason behind the need to implement the Green Economy concept. Therefore, the relevant agencies should campaign and promote knowledge to oil palm growers in order to forge understanding and awareness of oil palm cultivation under the Green Economy concept.

2) Farmers lacked incentives to operate under the Green Economy concept as they viewed that the Green Economy was not an immediate issue. They did not see clear benefits of farming according to the Green Economy concept. Especially the practice under the conceptual framework of the Green Economy was considered the increased production costs for the farmers. Therefore, in order to create incentives, the relevant agencies shoud render support. For example, the purchasing prices of oil palm from GAP certified plantations should be higher than from non GAP certified plantations to stimulate the farmers to become interested and committed to develop their own plantations to achieve standard certification in line with the Green Economy concept.

3) The obstacles that prevented the sustainable development of Thailand's oil palm industry were as follows. The public sector had a negative attitude towards the information, the private sector's comments, and lack of confidence of farmers' potential. Large entrepreneurs lacked confidence of the policy of agricultural land rent for growing palm trees. The government policy was inconsistent, depending on the rules, resulting in the lack of continuity and entrepreneurs' lack of confidence to invest. The government agencies lacked budget to implement the oil palm development plan. There was no unity in the development. As there was no agency with direct responsibility in controlling, monitoring, resulting in the lack of direction of clear and conformed development. There was the lack of government support to promote the cooperation between the private sector and small farmers. Moreover, the opening up of import resulted in more competition in the market. Lastly, the relative fluctuations of palm prices resulted in instability in the market.

4) Foster cooperation between relevant agencies, including the public, the private, and the oil palm grower sectors to create a strong network for the sustainable development of the oil palm industry under the conceptual framework of the Green Economy.

\section{Acknowledgement}

The researcher would like to thank National Research Council of Thailand for supporting the fund of the project of Green Economy in the Context of Thailand: A case study of Oil Palm Industry.

\section{References}

Abdullah, I., Wan Mahmood, W. H., Md Fauadi, M. H. F., Ab Rahman, M. N., \& Ahmad, F. (2015). Sustainability in Malaysian Palm Oil: A Review on Manufacturing Perspective. Polish Journal of Environmental Studies, 24, 1463-1475. https://doi.org/10.15244/pjoes/37888

Committee on agriculture of RSPO. (2014). RSPO standard requirements and certification guidelines for Oil-Palm farmers. Retrieved July 13, 2016, from www.rspo.org/publications/download/85d647748d94540 
Finco, M. V. A., \& Doppler, W. (2010). Bioenergy and sustainable development: The dilemma of food security and climate change in the Brazilian savannah. Energy for Sustainable Development, 14(3), 194-199. https://doi.org/10.1016/j.esd.2010.04.006

Harvey, M., \& Pilgrim, S. (2011). The new competition for land: Food, energy, and climate change. Food Policy, 36(Supplement 1), 40-51. https://doi.org/10.1016/j.foodpol.2010.11.009

Jaismut, P., Benchasri, S., Pruthikanee, P., Sanputawong, S., \& Simla, S. (2015). Study of sustainable oil palm production by the Standard of Roundtable on Sustainable Palm Oil in Krabi province. Retrieved August 13, 2016, from https://ag2.kku.ac.th/kaj

Ministry of Energy. (2017). Energy Situation January - December 2016. Retrieved April 12, 2017, from http://www.dede.go.th/ewt_news.php?nid=44623

Nit Sooksri. (2012). Participation of smallholder farmers in developing the Palm Oi market in Surat Thani province. Retrieved March 1, 2017, from http://elibrary.trf.or.th/project_content.asp

Office of Agricultural Economics. (2012). Greenhouse gas emissions of the oil palm industry. Retrieved September 15, 2016, from http://www4.dede.go.th

Office of Agricultural Economics. (2013). Study of greenhouse gas emissions from Oil Palm Cultivation in Thailand. Retrieved March 1, 2017, from http://www.oae.go.th

Office of Natural Resources and Environmental Policy and Planning. (2016). Thailand SCP Roadmap Development 2017 - 2036. Retrieved March 13, 2017, from http://www.onep. go.th /?p=1703

RSPO. (n.d.). RSPO standard requirements. Retrieved March 12, 2016, from https://www.rspo.org/publications/download/98d6564ef0e4582

Surat Thani Palm Oil Reserch Center. (n.d.). About palm oil. Retrieved October 1, 2016, from http://it.doa.go.th/palm/linkTechnical/know.html

Tan, K. T., Lee, K. T., \& Mohamed, A. R. (2009). Kinetics Study of Non Catalytic Supercritical Transesterification Reaction for Biodiesel Production. Energy Sources, Part A: Recovery, Utilization, and Environmental Effects, Taylor \& Francis (In Press).

Thailand Ministry of Energy. (2015). Alternative Energy Development Plan (AEDP 2015-2036). Retrieved January 1, 2017, from www.dede.go.th/download/files/AEDP2015_Final_version.pdf

Veerasak Rittiron. (2010). Good Agriculture Practices and oil palm Farmers hope. Retrieved January 1, 2017, from mueang.suratthani.doae.go.th/kmveerasak_181153.doc

\section{Copyrights}

Copyright for this article is retained by the author(s), with first publication rights granted to the journal.

This is an open-access article distributed under the terms and conditions of the Creative Commons Attribution license (http://creativecommons.org/licenses/by/4.0/). 